\title{
Calcium homeostasis in red blood cells of dialysis patients in dependence of erythropoietin treatment
}

\author{
Jue Wang ${ }^{1}$, Kai van Bentum ${ }^{2}$, Urban Sester ${ }^{3}$ and Lars Kaestner ${ }^{1 *}$ \\ ${ }^{1}$ Research Centre for Molecular Imaging and Screening, School of Medicine, Institute for Molecular Cell Biology, Saarland University, Homburg/Saar, Germany \\ ${ }^{2}$ Ambulatory Health Care Center Saarpfalz, Homburg/Saar, Germany \\ ${ }^{3}$ Internal Medicine IV, School of Medicine, Saarland University, Homburg/Saar, Germany \\ *Correspondence: lars_kaestner@me.com
}

Edited by:

Anna Bogdanova, University of Zurich, Switzerland

Reviewed by:

Joan-LLuis V. Corrons, University of Barcelona, Spain

Stéphane Egee, Station Biologique CNRS-UPMC, France

Keywords: erythrocyte, end-stage renal disease, calcium, EPO, haemodialysis, thrombotic events

Previous studies provided evidence for a massively increased intracellular $\mathrm{Ca}^{2+}$ concentration in red blood cells (RBCs) of patients with end-stage renal disease (ESRD) (Paschen et al., 1971; Gafter et al., 1989), whereas the dialysis procedure itself led in average to an even slightly decreased RBC's $\mathrm{Ca}^{2+}$ content (Paschen et al., 1971; Długaszek et al., 2008). Based on a single cell approach we could qualitatively confirm these results (Figure 1A, 2 leftmost columns), although the extend of the $\mathrm{Ca}^{2+}$ increase was smaller compared to the cited investigations, which is presumably caused by differences in the methodology.

There is a good knowledge of $\mathrm{Ca}^{2+}$ related processes in RBCs (Bogdanova et al., 2013). Additionally, an increased intracellular free $\mathrm{Ca}^{2+}$ concentration in RBCs has been proposed as a trigger for intracellular aggregation (Andrews and Low, 1999; Kaestner and Bernhardt, 2002) as well as for endothelium-RBC adhesion (Hebbel et al., 1980; Mohandas and Evans, 1985) and experimental evidence has been provided (Noh et al., 2010; Steffen et al., 2011; Borst et al., 2012; Kaestner et al., 2012).

The molecular identity of $\mathrm{Ca}^{2+}$ - and non-selective cation channels in the RBC membrane is steadily increasing (Kaestner, 2011) and comprise of, e.g., the $\mathrm{Ca}_{\mathrm{V}} 2.1$ (Andrews et al., 2002), the TRPC6 (Foller et al., 2008), the NMDA-receptor (Makhro et al., 2013), and the Piezol (Zarychanski et al., 2012).

The effect of erythropoietin (EPO) on RBCs ion homeostasis is controversially discussed. The group of Florian Lang found an inhibition of non-selective cation channels by EPO with a decreased number of eryptotic RBCs if patients were treated with EPO (Myssina et al., 2003). However, once $\mathrm{Ca}^{2+}$ entered the $\mathrm{RBC}$, EPO has no beneficial effect toward the eryptotic symptoms caused by $\mathrm{Ca}^{2+}$ (Vota et al., 2013). In contrast to RBCs, hematopoietic progenitor cells display an increased cation-channel activity upon EPO exposure (Cheung et al., 1997; Tong et al., 2008). Because of its hematopoiesis stimulating properties, EPO became a widely used medication for treatment of anemic patients, including chronic renal disease, hematologic disorders, and acquired immune deficiency syndrome (Palmer et al., 2010; Goodnough and Shander, 2013). However, several studies highlighted the problem of an increased risk of thrombus formation, especially venous thromboembolism, in patients undergoing EPO therapy (Singbartl, 1994; Kliger et al., 2012; Goodnough and Shander, 2013).

Therefore we investigated the free $\mathrm{Ca}^{2+}$ concentration in RBCs from ESRD (dialysis) patients under EPO treatment. Blood samples from healthy donors, ESRD patients and EPO treated ESRD patients were analyzed by fluorescence live cell imaging as previously described (Wang et al., 2013) (Figure 1). As depicted in Figure 1A, at rest, RBCs from ESRD patients show higher $\mathrm{Ca}^{2+}$ concentration compared with healthy donors, while EPO treatment let to a slightly decreased free internal $\mathrm{Ca}^{2+}$ concentration, indicating an inhibition of constitutively active channels in resting RBCs. Although the histograms (Figure 1 Ab) give an impression of the distribution, the method lacks quantitative information concerning the $\mathrm{Ca}^{2+}$ concentration (Kaestner et al., 2006). However, when compared to control conditions, the width of the distribution of $\mathrm{Ca}^{2+}$ content is wider in ESRD patients or EPO-treated ESRD patients, leading to the conclusion that the cellular heterogeneity is greater in patients than in healthy subjects. In a further step we investigated the $\mathrm{Ca}^{2+}$ influx in RBC from healthy donors and ESRD patients after hormonal stimulation in dependence of EPO treatment (Figure 1B). As a stimulation substance we selected prostaglandin $\mathrm{E}_{2}\left(\mathrm{PGE}_{2}\right)$, which is released from activated platelets (Smith et al., 1973) but can also be released from RBCs themselves when they pass small capillaries (Oonishi et al., 1998). The curves in Figure 1Ba present typical example traces for $\mathrm{Ca}^{2+}$ curves in RBCs, while Figure $\mathbf{1 B b}$ shows the statistical analysis. Healthy patients show an increase in $\mathrm{Ca}^{2+}$ after $\mathrm{PGE}_{2}$ stimulation as we have previously shown (Kaestner et al., 2004). EPO treatment prevents $\mathrm{Ca}^{2+}$ entry resulting in $\mathrm{Ca}^{2+}$ levels below control conditions confirming the results of the Lang group (Myssina et al., 2003). However, pretreatment with EPO even suppressed the $\mathrm{Ca}^{2+}$ entry provoked by $\mathrm{PGE}_{2}$. In ESRD patients, $\mathrm{PGE}_{2}$ stimulation leads to a $\mathrm{Ca}^{2+}$ increase, which is significantly higher than in RBCs of healthy donors. In EPO treated ESRD patients the $\mathrm{PGE}_{2}$ induced $\mathrm{Ca}^{2+}$ increase was significantly suppressed compared to RBCs of 


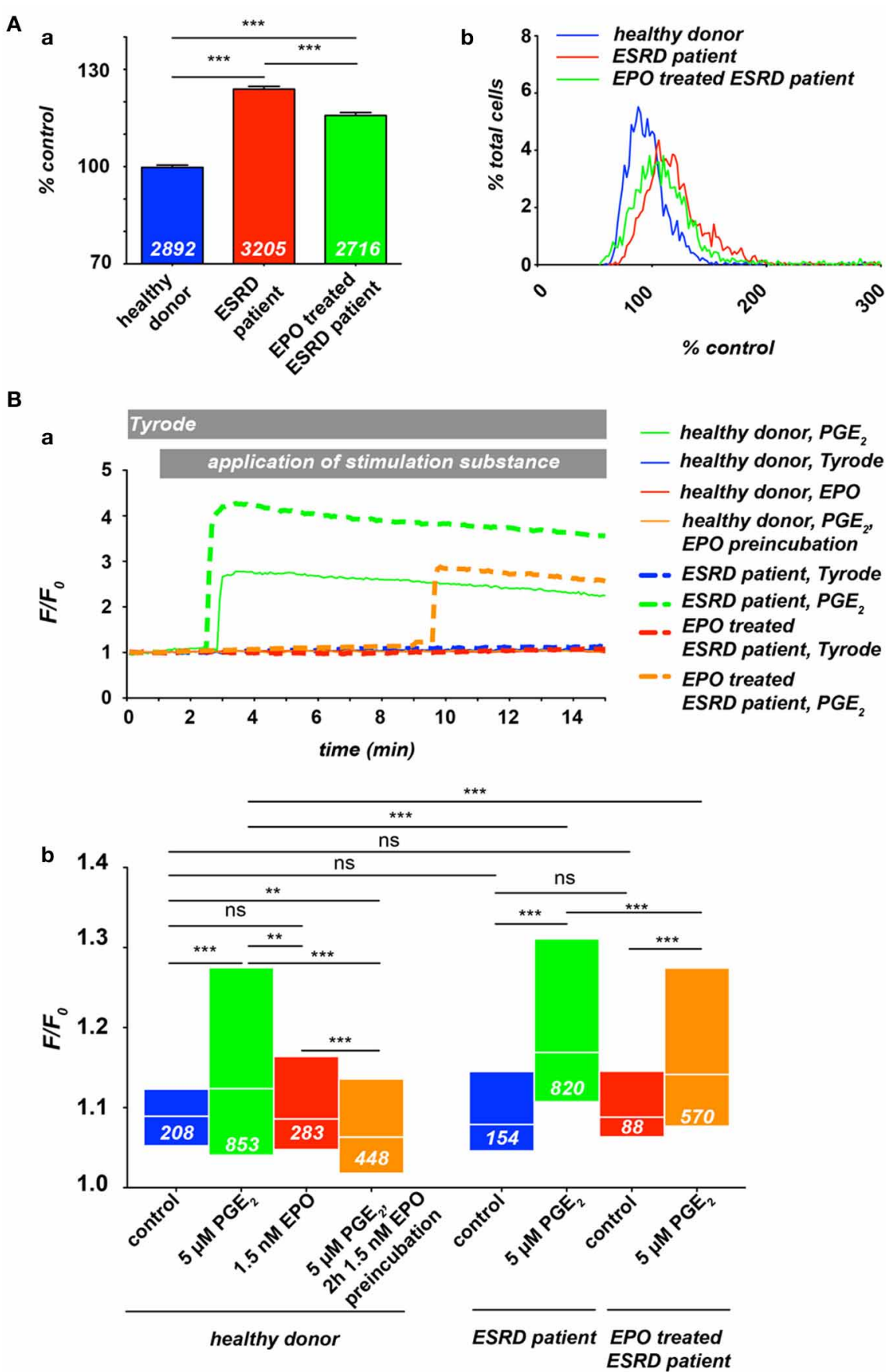

FIGURE $1 \mid \mathrm{Ca}^{2+}$ in RBCs of healthy donors and end-stage renal disease (ESRD) patients with a renal anaemia. If patients were under EPO treatment, the last EPO administration was within 5 days of blood sampling. All experimental procedures are previously described in detail (Wang et al., 2013). (A) Resting $\mathrm{Ca}^{2+}$ in terms of relative Fluo-4 fluorescence intensity of RBCs suspended in plasma. (Aa) Statistical analysis of $\mathrm{RBC} \mathrm{Ca}{ }^{2+}$ of at least 3 individuals in each group. The white numbers indicate the number of cells analyzed and the error bars represent standard error of mean. (Ab) Histograms of the relative fluorescence intensity distribution of the measurements presented in (Aa). (B) Intracellular $\mathrm{Ca}^{2+}$-traces in $\mathrm{RBCs}$ under different conditions: control (Tyrode solution containing in mM: $135 \mathrm{NaCl}, 5.4 \mathrm{KCl}, 10$ glucose, $1 \mathrm{MgCl}_{2}, 1.8 \mathrm{CaCl}_{2}$ and $10 \mathrm{HEPES}$; the $\mathrm{pH}$ was adjusted to 7.35 using
$\mathrm{NaOH}$ ) or stimulation with $5 \mu \mathrm{M} \mathrm{PGE}_{2}$ and/or $1.5 \mathrm{nM}$ EPO. (Ba) Typical example traces of Fluo-4 fluorescence intensity over time for all conditions tested. Traces were chosen due to their typical intensity of response, which are analyzed in $\mathbf{( B b})$. Differences in the onset of the response were equally distributed over a wide range for all conditions tested (data not shown). However, it is worthwhile to mention that in case of stimulation only a limited number of cells are responders (Kaestner et al., 2004), which explains the difference in normalized fluorescence intensity $\left(F / F_{0}\right)$ between the example traces and the statistical analysis of the entire cell population measured. The white numbers indicate the number of cells analyzed. For the statistical evaluation a Mann-Whitney test was performed and the following convention was used: ${ }^{* *} p<0.001,{ }^{* *} p<0.01$, and ns $p>0.05$. 
non-treated patients even in the putative absence of EPO during the experiment.

The results of Figure 1 suggest that the clinically observed thrombotic complications in patients treated with EPO seem not to be primarily caused by an elevated $\mathrm{Ca}^{2+}$ content of RBCs of these patients. However, it is hypothesized that EPO causes thrombosis as a result of inflammation (Tobu et al., 2004). The elevated basal $\mathrm{Ca}^{2+}$ level in RBCs of ESRD patients (Paschen et al., 1971; Gafter et al., 1989; Figure 1A) may enhance a blood clotting once initiated by an inflammation processes. It is a substantial finding that the response of $\mathrm{RBC}$ to hormonal stimulation or other treatments, like the dialysis itself, in terms of $\mathrm{Ca}^{2+}$ entry shows a wide variation between RBC within a population, but also between different individuals (Paschen et al., 1971; Wang et al., 2013; Figure 1Ba).

In light of the above statements concerning the thrombotic events and the molecular players, the perspective of medical treatment must be based on a personalized diagnosis followed by a personalized medication. This applies to ESRD patients as well as for treatments of other anemias. Techniques and procedures allowing such an individualized approach presumably based on the combination of RBC population measurements and single cell techniques (Minetti et al., 2013) need urgently to be developed.

\section{ACKNOWLEDGMENTS}

The research leading to these results has received funding from the European Seventh Framework Program under grant agreement number 602121.

\section{REFERENCES}

Andrews, D. A., and Low, P. S. (1999). Role of red blood cells in thrombosis. Curr. Opin. Hematol. 6, 76-82. doi: 10.1097/00062752-199903000-00004

Andrews, D. A., Yang, L., and Low, P. S. (2002). Phorbol ester stimulates a protein kinase Cmediated agatoxin-TK-sensitive calcium permeability pathway in human red blood cells. Blood 100, 3392-3399. doi: 10.1182/blood.V100.9.3392

Bogdanova, A., Makhro, A., Wang, J., Lipp, P., and Kaestner, L. (2013). Calcium in red blood cells-a perilous balance. Int. J. Mol. Sci. 14, 9848-9872. doi: 10.3390/ijms14059848

Borst, O., Abed, M., Alesutan, I., Towhid, S. T., Qadri, S. M., Foller, M., et al. (2012). Dynamic adhesion of eryptotic erythrocytes to endothelial cells via CXCL16/SR-PSOX. Am. J. Physiol. Cell Physiol. 302, C644-C651. doi: 10.1152/ajpcell.00340.2011
Cheung, J. Y., Zhang, X. Q., Bokvist, K., Tillotson, D. L., and Miller, B. A. (1997). Modulation of calcium channels in human erythroblasts by erythropoietin. Blood 89, 92-100.

Długaszek, M., Szopa, M., Rzeszotarski, J., and Karbowiak, P. (2008). Magnesium, calcium and trace elements distribution in serum, erythrocytes, and hair of patients with chronic renal failure. Magnes. Res. 21, 109-117. doi: 10.1684/mrh.2008.0135

Foller, M., Kasinathan, R. S., Koka, S., Lang, C., Shumilina, E. V., Birnbaumer, L., et al. (2008). TRPC6 contributes to the $\mathrm{Ca}(2+)$ leak of human erythrocytes. Cell. Physiol. Biochem. 21, 183-192. doi: 10.1159/000113760

Gafter, U., Malachi, T., Barak, H., Djaldetti, M., and Levi, J. (1989). Red blood cell calcium homeostasis in patients with end-stage renal disease. J. Lab. Clin. Med. 114, 222-231.

Goodnough, L. T., and Shander, A. (2013). Update on erythropoiesis-stimulating agents. Best Pract. Res. Clin. Anaesthesiol. 27, 121-129. doi: 10.1016/j.bpa.2012.11.006

Hebbel, R. P., Yamada, O., Moldow, C. F., Jacob, H. S., White, J. G., and Eaton, J. W. (1980). Abnormal adherence of sickle erythrocytes to cultured vascular endothelium: possible mechanism for microvascular occlusion in sickle cell disease. J. Clin. Invest. 65, 154-160. doi: 10.1172/JCI109646

Kaestner, L. (2011). Cation channels in erythrocytes - historical and future perspective. Open Biol. J. 4, 27-34. doi: 10.2174/1874196701104010027

Kaestner, L., and Bernhardt, I. (2002). Ion channels in the human red blood cell membrane: their further investigation and physiological relevance. Bioelectrochemistry 55, 71-74. doi: 10.1016/S15675394(01)00164-5

Kaestner, L., Steffen, P., Nguyen, D. B., Wang, J., Wagner-Britz, L., Jung, A., et al. (2012). Lysophosphatidic acid induced red blood cell aggregation in vitro. Bioelectrochemistry 87, 89-95. doi: 10.1016/j.bioelechem.2011.08.004

Kaestner, L., Tabellion, W., Lipp, P., and Bernhardt, I. (2004). Prostaglandin E2 activates channelmediated calcium entry in human erythrocytes: an indication for a blood clot formation supporting process. Thromb. Haemost. 92, 1269-1272. doi: 10.1160/TH04-06-0338

Kaestner, L., Tabellion, W., Weiss, E., Bernhardt, I. and Lipp, P. (2006). Calcium imaging of individual erythrocytes: problems and approaches. Cell Calcium 39, 13-19. doi: 10.1016/j.ceca.2005. 09.004

Kliger, A. S., Fishbane, S., and Finkelstein, F. O. (2012). Erythropoietic stimulating agents and quality of a patient's life: individualizing anemia treatment. Clin. J. Am. Soc. Nephrol. 7, 354-357. doi: 10.2215/CJN.11961111

Makhro, A., Hanggi, P., Goede, J., Wang, J., Bruggemann, A., Gassmann, M., et al. (2013). (NMDA) receptors in human erythroid precursor cells and in circulating red blood cells contribute to the intracellular calcium regulation. Am. J. Physiol. Cell. Physiol. 305, C1123-C1138. doi: 10.1152/ajpcell.00031.2013

Minetti, G., Egée, S., Mörsdorf, D., Steffen, P., Makhro, A., Achilli, C., et al. (2013). Red cell investigations: art and artefacts. Blood Rev. 27, 91-101. doi: 10.1016/j.blre.2013.02.002
Mohandas, N., and Evans, E. (1985). Sickle erythrocyte adherence to vascular endothelium. Morphologic correlates and the requirement for divalent cations and collagen-binding plasma proteins. J. Clin. Invest. 76, 1605-1612. doi: 10.1172/JCI112144

Myssina, S., Huber, S. M., Birka, C., Lang, P. A., Lang, K. S., Friedrich, B., et al. (2003). Inhibition of erythrocyte cation channels by erythropoietin. J. Am. Soc. Nephrol. 14, 2750-2757. doi: 10.1097/01.ASN.0000093253.42641.C1

Noh, J.-Y., Lim, K.-M., Bae, O.-N., Chung, S.-M., Lee, S.-W., Joo, K.-M., et al. (2010). Procoagulant and prothrombotic activation of human erythrocytes by phosphatidic acid. Am. J. Physiol. Heart Circ. Physiol. 299, H347-H355. doi: 10.1152/ajpheart.01144.2009

Oonishi, T., Sakashita, K., Ishioka, N., Suematsu, N., Shio, H., and Uyesaka, N. (1998). Production of prostaglandins E1 and E2 by adult human red blood cells. Prostaglandins Other Lipid Mediat. 56, 89-101. doi: 10.1016/S0090-6980(98)00045-8

Palmer, S. C., Navaneethan, S. D., Craig, J. C., Johnson, D. W., Tonelli, M., Garg, A. X., et al. (2010). Meta-analysis: erythropoiesis-stimulating agents in patients with chronic kidney disease. Ann. Intern. Med. 153, 23-33. doi: 10.7326/00034819-153-1-201007060-00252

Paschen, K., Henning, H. V., Quellhorst, E., and Scheler, F. (1971). Veränderungen der calciumund magnesiumkonzentrationen im plasma und in erythrocyten während der hämodialyse. Klin. Wochenschr. 49, 1314-1318. doi: 10.1007/BF01495517

Singbartl, G. (1994). Adverse events of erythropoietin in long-term and in acute/short-term treatment. Clin. Investig. 72, S36-43.

Smith, J. B., Ingerman, C., Kocsis, J. J., and Silver, M. J. (1973). Formation of prostaglandins during the aggregation of human blood platelets. J. Clin. Invest. 52, 965-969. doi: 10.1172/JCI107262

Steffen, P., Jung, A., Nguyen, D. B., Müller, T., Bernhardt, I., Kaestner, L., et al. (2011). Stimulation of human red blood cells leads to $\mathrm{Ca}^{2+}$-mediated intercellular adhesion. Cell Calcium 50, 54-61. doi: 10.1016/j.ceca.2011.05.002

Tobu, M., Iqbal, O., Fareed, D., Chatha, M., Hoppensteadt, D., Bansal, V., et al. (2004). Erythropoietin-induced thrombosis as a result of increased inflammation and thrombin activatable fibrinolytic inhibitor. Clin. Appl. Thromb. Hemost. 10, 225-232. doi: 10.1177/107602960401000304

Tong, Q., Hirschler-Laszkiewicz, I., Zhang, W., Conrad, K., Neagley, D. W., Barber, D. L., et al. (2008). TRPC3 is the erythropoietinregulated calcium channel in human erythroid cells. J. Biol. Chem. 283, 10385-10395. doi: 10.1074/jbc.M710231200

Vota, D. M., Maltaneri, R. E., Wenker, S. D., Nesse, A. B., and Vittori, D. C. (2013). Differential erythropoietin action upon cells induced to eryptosis by different agents. Cell. Biochem. Biophys. 65, 145-157. doi: 10.1007/s12013-012-9408-4

Wang, J., Wagner-Britz, L., Bogdanova, A., Ruppenthal, S., Wiesen, K., Kaiser, E., et al. (2013). Morphologically homogeneous red blood cells present a heterogeneous response to hormonal stimulation. PLOS ONE 8:e67697. doi: 10.1371/journal.pone.0067697 
Zarychanski, R., Schulz, V. P., Houston, B. L., Maksimova, Y., Houston, D. S., Smith, B., et al. (2012). Mutations in the mechanotransduction protein PIEZO1 are associated with hereditary xerocytosis. Blood 120, 1908-1915. doi: 10.1182/blood-2012-04-422253

Received: 01 November 2013; accepted: 09 January 2014; published online: 27 January 2014.
Citation: Wang J, van Bentum K, Sester U and Kaestner $L$ (2014) Calcium homeostasis in red blood cells of dialysis patients in dependence of erythropoietin treatment. Front. Physiol. 5:16. doi: 10.3389/fphys.2014.00016

This article was submitted to Membrane Physiology and Membrane Biophysics, a section of the journal Frontiers in Physiology.

Copyright (c) 2014 Wang, van Bentum, Sester and Kaestner. This is an open-access article distributed under the terms of the Creative Commons Attribution License (CC BY). The use, distribution or reproduction in other forums is permitted, provided the original author(s) or licensor are credited and that the original publication in this journal is cited, in accordance with accepted academic practice. No use, distribution or reproduction is permitted which does not comply with these terms. 